\title{
Effectiveness of plant growth promoting rhizobacteria in facilitating lead and nutrient uptake by little seed canary grass
}

\author{
FAEZEH ZAEFARIAN ${ }^{1}$, SAMANEH VAHIDZADEH ${ }^{2}$, PARVANEH RAHDARI ${ }^{2}$, \\ MOHAMMAD REZVANI ${ }^{3}$ and HOSSEIN GHANI ZADEH ${ }^{4,5}$
}

(received: July 10, 2012; accepted: August 23, 2012)

\begin{abstract}
Effectiveness of plant growth promoting rhizobacteria in facilitating lead and nutrient uptake by little seed canary grass). We investigated the effectiveness of Nitroxin inoculation on lead $(\mathrm{Pb})$ and nutrient uptakes by little seed canary grass. The factors tested included inoculation (or not) with Nitroxin and different soil concentrations of $\mathrm{Pb}(0,200,400$ and $800 \mathrm{mgPb} \mathrm{kg}^{-1}$ soil). Increasing soil concentrations of $\mathrm{Pb}$ decreased stem, leaf and root dry weights. Shoot phosphorus concentrations increased in parallel with increasing soil $\mathrm{Pb}$ concentrations. Nitroxin inoculation did not alter the phosphorus concentration of the roots. The $\mathrm{Pb}$ translocation factor was $>1$ in inoculated treatments in the $\mathrm{Pb}$ soil concentration range of 200 to $400 \mathrm{mg} \mathrm{kg}^{-1}$; the translocation factor for $800 \mathrm{mgPb} \mathrm{kg}^{-1}$ with no inoculation of Nitroxin was, however, $<1$. Our results indicated that the $\mathrm{Pb}$ bioaccumulation factor for little seed canary grass was $<1$, indicating that it is a $\mathrm{Pb}$ excluding plant.
\end{abstract}

Key words - bioaccumulation factor, heavy metals, Phalaris minor, translocation factor

\section{INTRODUCTION}

Heavy metals are some of the most dangerous substances in the environment due to their persistence and harmfulness to living organisms (Henry 2000). Lead is one of the major contaminants of soils, sediments, and water, and it can adversely affect the central and peripheral nervous systems, hematopoietic system, kidneys, gastrointestinal tract, liver, myocardium, and reproductive systems of animals (Tintinelli et al. 1992).

Phytoremediation techniques use plants to extract environmental contaminants or to render them innocuous (Salt et al. 1998) and represent an eco-friendly approach to pollution site decontamination (Suresh and Ravishankar 2004).

Studies of the interactions between plant roots and diverse soil microbiota (such as fungi, bacteria and their associated microfauna) are important for elucidating ecological interactions between plants, microbes, soils, and climatic factors in the phytoremediation of contaminated soils (Khan 2006). The impact of microbiological processes on the decontamination of environments polluted by toxic metals and radioactive substances can be quite significant from an economic and environmental point of view (Gadd 2001). However,

1. Sari Agricultural Sciences and Natural Resources University, Department of Agronomy and Plant Breeding, Sari, Iran.

2. Islamic Azad University, Department of Biology, Tonekabon Branch, Tonekabon, Iran.

3. Islamic Azad University, Department of Weed Science, Qaemshahr Branch, Iran.

4. Massey University, Institute of Natural Resources, Private Bag 11 222, Palmerston North, New Zealand.

5. Corresponding author: H.GhaniZadeh@massey.ac.nz the physical and chemical natures of the sites may influence the effectiveness of microbial bioremediation processes, as they can affect the form in which heavy metals occur (Van der Lelie et al. 2001). The rhizosphere comprises mycorrhization helper bacteria (MHB) and plant growth promoting rhizobacteria (PGPR) (Andrade et al. 1997), P-solubilizers, free-living and symbiotic nitrogen fixers, antibiotic producing rhizobacteria, plant pathogens, predators, and parasites (Sun et al. 1999). Rhizospheric PGPR bacteria can promote plant root establishment and durability by adhering to root surfaces and using root exudates for growth by synthesizing amino acids and vitamins and colonizing the developing root system (Frankenberger et al. 1996). The rhizospheric competence of introduced PGPRs can be affected, however, by quantitative and qualitative variations in root exudates during plant growth (Khan 2006). PGPRs can enhance plant growth directly by providing bio-available phosphorus for plant uptake, fixing nitrogen for plant use, sequestering trace elements such as iron for plants, producing plant hormones such as auxins, cytokinins and gibberellins, and by lowering plant ethylene levels (Glick et al. 1999).

The use of weeds for the phytoremediation of heavy metal-contaminated lands appears to have considerable potential. Little seed canary grass (Phalaris minor L.; family Poaceae) - LSCG, is one of the most abundant annual weeds found in Iran, grows very rapidly with high biomass production and a dense root system. There is currently no data available on the effects of $\mathrm{Pb}$ and PGPR on the growth of LSCG. The present study therefore investigated the responses of little seed canary grass to $\mathrm{Pb}$, as well as the effects of PGPR inoculation on plant 
biomass production, $\mathrm{Pb}$ concentrations in roots and shoots, and the uptake and translocation of nutrients (including nitrogen $[\mathrm{N}]$ and phosphorus $[\mathrm{P}]$ ) by this grass.

\section{MATERIAL AND METHODS}

The experiments were performed under greenhouse conditions. Soil was collected from the top $20 \mathrm{~cm}$ layer from arable lands, then air dried and subsequently sieved $(<2 \mathrm{~mm}$ mesh) before use. The soil was analyzed for the following properties: soil texture [clay (29.4\%), silt (51.4\%), sand $(19.2 \%)$ ], electrical conductivity $\left(\mathrm{EC}, 2.06 \mathrm{~d} \mathrm{Sm}^{-1}\right)$, organic carbon (OC, $0.41 \%)$, total $\mathrm{N}(0.041 \%)$, available $\mathrm{P}$ (4.84 mg kg-1), $\mathrm{K}\left(125 \mathrm{mg} \mathrm{kg}^{-1}\right)$, as well as for $\mathrm{Pb}$ (1.19 $\mathrm{mg} \mathrm{kg}^{-1}$ dry soil). Five kilograms of soil were placed into individual pots and subsequently contaminated with four different concentrations of $\mathrm{Pb}\left(\mathrm{as}\left(\mathrm{Pb}\left(\mathrm{NO}_{3}\right)_{2}\right)\right.$ (Merck, Germany) (at $0,200,400$ and $800 \mathrm{mgP} \mathrm{kg}^{-1}$ soil), plus uncontaminated controls, with three replicates each.

Ten seeds of LSCG were sown in each pot with or without inoculation of Nitroxin (a biofertilizer that containing nitrogen fixing bacteria, including Azotobacter and Azospirillum) then thinned to five plant per pot at four leaf stage.

Seeds were collected from wheat fields and kept at room temperature for one year. The pots were maintain under glasshouse conditions at $25 / 10{ }^{\circ} \mathrm{C}$ day/night temperatures, under natural solar radiation. Pot were irrigated daily. LSCG is a very fast growing plant and is able to withstand adverse environmental conditions.

\section{$\mathrm{Pb}$ and nutrient analyses}

Plant samples were divided into stems, leaves, and roots, washed thoroughly with distilled water, and then oven dried at $70{ }^{\circ} \mathrm{C}$ for $24 \mathrm{~h}$ before further analysis. The dry biomass of plant materials was recorded. The plant material was then ground up and digested in 3:1 $\mathrm{HNO}_{3}$ and $\mathrm{HClO}_{4}($ Merck) (v/v) overnight. The concentrations of $\mathrm{Pb}$ were determined using atomic absorption spectrophotometry (M SERIES; Thermo, China) (Sun et al. 2005) using $\mathrm{Pb}\left(\mathrm{NO}_{3}\right)_{2}$ as a standard. Total $\mathrm{N}$ and total $\mathrm{P}$ were quantified by using the Berthelot reaction and the molybdenum blue method respectively (Page et al. 1982).

\section{Pb Translocation Factor (TF)}

$\mathrm{Pb}$ translocations from roots to shoots were measured by calculating the TF, as given below:

$$
\mathrm{TF}=\mathrm{C}_{\text {shoot }} / \mathrm{C}_{\text {root }}(1)
$$

Where $\mathrm{C}_{\text {shoot }}$ and $\mathrm{C}_{\text {root }}$ represent the heavy-metal concentrations in the plant shoots $\left(\mathrm{mg} \mathrm{kg}^{-1}\right)$ and roots $\left(\mathrm{mg} \mathrm{kg}^{-1}\right)$ respectively. TF values $>1$ indicate that $\mathrm{Pb}$ is effectively translocated from the roots to the shoots (Zhang et al. 2002, Fayiga \& Ma 2006).

\section{Pb Bioaccumulation Factor (BAF)}

The bioaccumulation factor (BAF) of $\mathrm{Pb}$ was calculated by:

$$
\mathrm{BAF}=\mathrm{C}_{\text {shoot }} / \mathrm{C}_{\text {soil }}(2)
$$

Where $\mathrm{C}_{\text {shoot }}$ and $\mathrm{C}_{\text {soil }}$ represent the heavy-metal concentrations in the plant shoots $\left(\mathrm{mg} \mathrm{kg}^{-1}\right)$ and the soils $\left(\mathrm{mg} \mathrm{kg}^{-1}\right)$ respectively. Plants are classified as hyperaccumulators, accumulators, or excluders based on BAF values $>1 \mathrm{mg} \mathrm{kg}^{-1}$, equal to 1 , or $<1 \mathrm{mg} \mathrm{kg}^{-1}$ respectively (Ma et al. 2001, Cluis 2004).

\section{Statistical analysis}

Data were subjected to analysis of variance, and the means were compared using LSD at $P<0.05$. SAS software (version 9.1) was used for all statistical analyses.

\section{RESULTS}

\section{Plant biomass}

Inoculation with Nitroxin had no significant effects on leaf or root dry weight gains, but markedly influenced stem dry weights (table 1). Nitroxin and lead interactions significantly affected the leaf, stem, and

Table 1. Analysis of variance of the effects of Nitroxin and $\mathrm{Pb}$ treatments on plant biomass and its $\mathrm{N}, \mathrm{P}$ and $\mathrm{Pb}$ contents. (S.O.V = Source of variations; $\mathrm{CV}=$ coefficient variation)

\begin{tabular}{lccccccccc}
\hline & \multicolumn{1}{c}{ Mean square (MS) } \\
\cline { 2 - 9 } S.O.V. & $\begin{array}{c}\text { Leaf dry } \\
\text { weight }\end{array}$ & $\begin{array}{c}\text { Stem dry } \\
\text { weight }\end{array}$ & $\begin{array}{c}\text { Root dry } \\
\text { weight }\end{array}$ & $\begin{array}{c}\text { Shoot } \\
\mathrm{N}\end{array}$ & $\begin{array}{c}\text { Root } \\
\mathrm{N}\end{array}$ & $\begin{array}{c}\text { Shoot } \\
\mathrm{P}\end{array}$ & $\begin{array}{c}\text { Root } \\
\mathrm{P}\end{array}$ & $\begin{array}{c}\text { Shoot } \\
\mathrm{Pb}\end{array}$ & $\begin{array}{c}\text { Root } \\
\mathrm{Pb}\end{array}$ \\
\hline Nitroxin & $13.83^{\text {ns }}$ & $44.28^{*}$ & $0.02^{\text {ns }}$ & $0.84^{*}$ & $0.13^{*}$ & $0.02^{*}$ & $0.004^{*}$ & $0.003^{\text {ns }}$ & $0.002^{\text {ns }}$ \\
$\mathrm{Pb}$ & $136.21^{*}$ & $47.51^{*}$ & $3.21^{*}$ & $1.02^{*}$ & $0.14^{*}$ & $0.001^{*}$ & $0.01^{*}$ & $0.05^{*}$ & $0.22^{*}$ \\
Nitroxin* $\mathrm{Pb}$ & $45.22^{*}$ & $15.37^{*}$ & $0.371^{*}$ & $0.29^{*}$ & $0.17^{*}$ & $0.008^{*}$ & $0.013^{*}$ & $0.03^{\text {ns }}$ & $0.008^{\text {ns }}$ \\
Error & 4.39 & 0.97 & 0.09 & 0.03 & 0.01 & 0.004 & 0.0008 & 0.01 & 0.009 \\
$\mathrm{CV}(\%)$ & 8.94 & 3.60 & 10.20 & 6.75 & 11.42 & 6.68 & 7.37 & 9.91 & 8.66 \\
\hline
\end{tabular}

* Statistically significant at $P<0.05$; ns = nonsignificant. 
root dry weights of the plants (table 1). Irrespective of the presence or not of Nitroxin, leaf biomass decreased as soil $\mathrm{Pb}$ concentrations increased (figure 1). Among plants grown without Nitroxin inoculation, maximum stem biomass was observed in the control treatment: soil $\mathrm{Pb}$ concentrations up to $200 \mathrm{mgPb} \mathrm{kg}{ }^{-1}$ decreased stem dry weights; in the range of 200 to $400 \mathrm{mgPb} \mathrm{kg}^{-1}$ dry soil, stem dry weights did not change; stem dry weights then decreased as soil $\mathrm{Pb}$ concentrations increased to $800 \mathrm{mgPb} \mathrm{kg}^{-1}$ (figure 2). $\mathrm{Pb}$ caused decreases in leaf biomasses with or without Nitroxin inoculation (figure 2). We also found that increasing soil $\mathrm{Pb}$ concentrations reduced root dry weight (figure 3 ). Minimum root growth was observed at $800 \mathrm{mgPb} \mathrm{kg}^{-1}$ dry soil (figure 3).

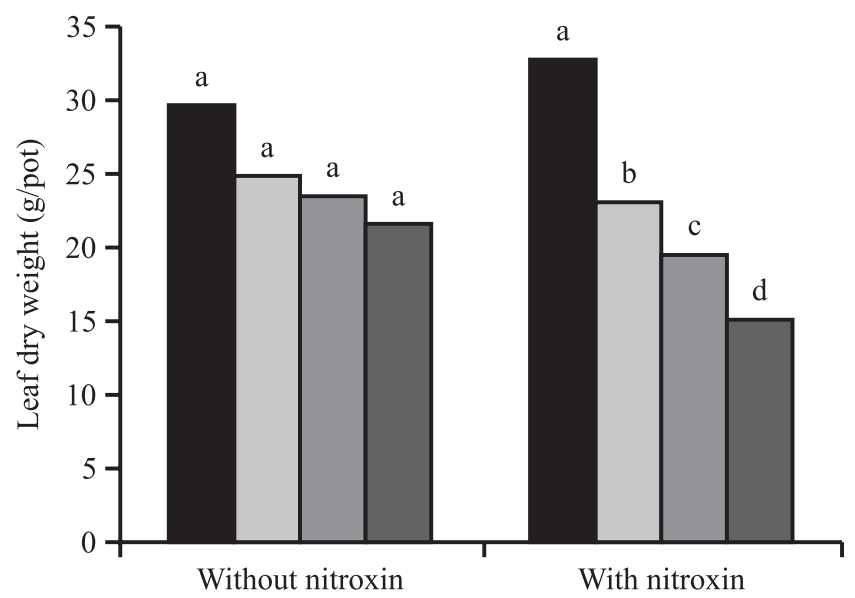

Figure 1. Effects of the interactions between Nitroxin and lead concentrations on leaf dry weights. Columns with the same letter in each group are not significantly different at a $5 \%$ level of probability. ( $\boldsymbol{\square}=$ Control; $\square=200 \mathrm{mgPb} \mathrm{kg}{ }^{-1}$; $\left.\square=400 \mathrm{mgP} \mathrm{kg}^{-1} ; \square=800 \mathrm{mgPb} \mathrm{kg}^{-1}\right)$.

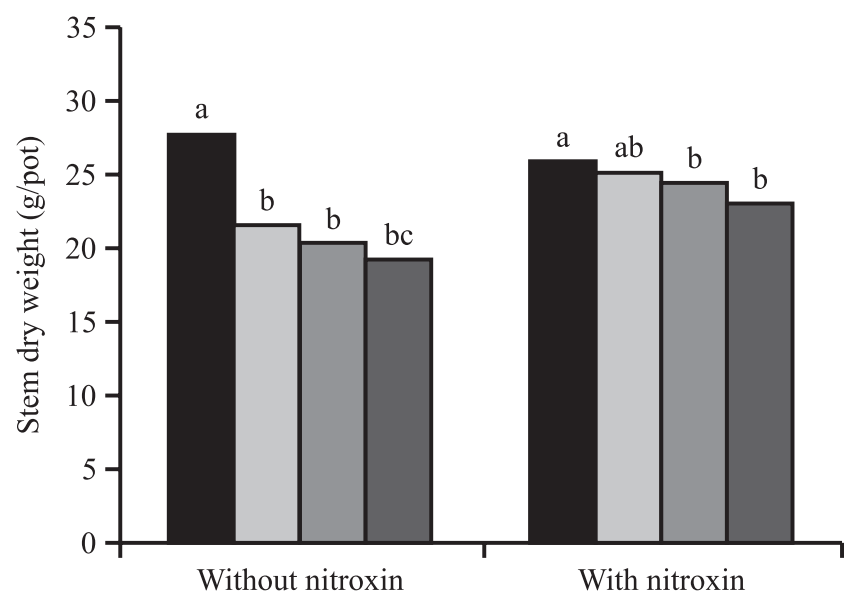

Figure 2. Effects of the interactions between Nitroxin and lead concentrations on stem dry weights. Columns with the same letter in each group are not significantly different at a $5 \%$ level of probability. ( $=$ Control; $\square=200 \mathrm{mgP} \mathrm{kg}^{-1}$; $\left.\square=400 \mathrm{mgPb} \mathrm{kg}^{-1} ; \square=800 \mathrm{mgP} \mathrm{kg}^{-1}\right)$.

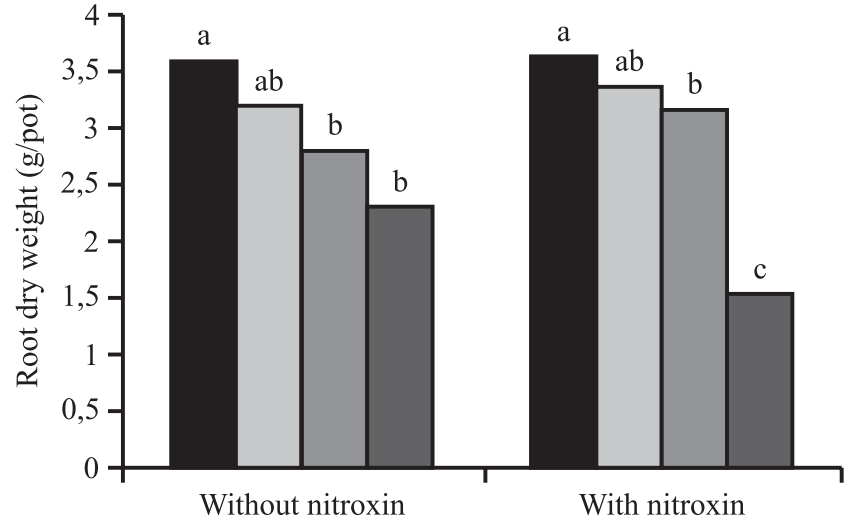

Figure 3. Effects of the interactions between Nitroxin and lead concentrations on root dry weights. Columns with the same letter in each group are not significantly different at a $5 \%$ level of probability. ( $\square=$ Control; $\square=200 \mathrm{mgP} \mathrm{kg} \mathrm{k}^{-1}$; $\left.\square=400 \mathrm{mgPb} \mathrm{kg}^{-1} ; \square=800 \mathrm{mgPb} \mathrm{kg}^{-1}\right)$.

\section{Shoot and root nitrogen concentrations}

Nitroxin inoculation and $\mathrm{Pb}$ soil concentrations had significant impacts on shoot nitrogen concentrations (table 1 ). Pb significantly affected nitrogen concentration in the shoots of little seed canary grass in all treatments (figure 4). Maximum shoot nitrogen concentrations were found at soil $\mathrm{Pb}$ concentration of $800 \mathrm{mg} \mathrm{kg}^{-1}$ both with and without PGPR inoculation (figure 4).

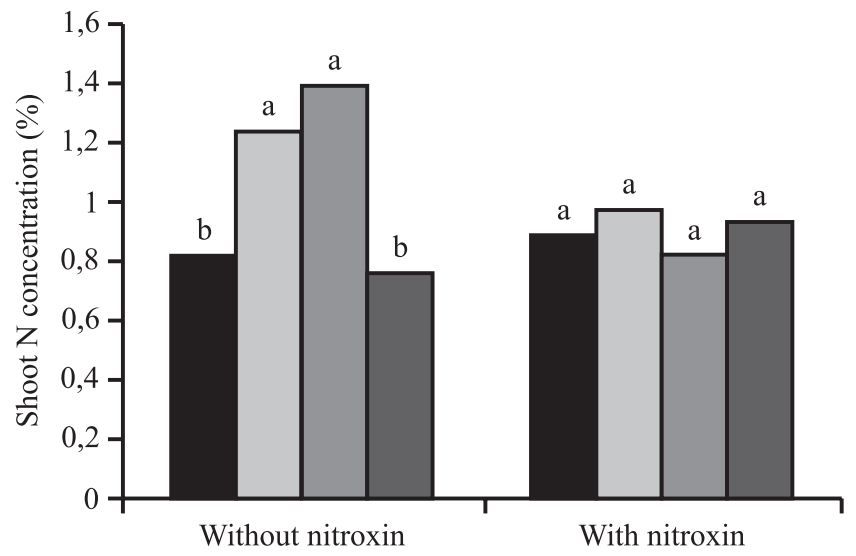

Figure 4. Effects of the interactions between Nitroxin and lead concentrations on shoot nitrogen concentrations. Columns with the same letter in each group are not significantly different at a $5 \%$ level of probability. ( $\boldsymbol{(}=$ Control; $\square=200 \mathrm{mgPb} \mathrm{kg}^{-1}$; $\left.\square=400 \mathrm{mgPb} \mathrm{kg}^{-1} ; \square=800 \mathrm{mgP} \mathrm{kg}^{-1}\right)$.

When LSCG was grown in un-inoculated soils, $\mathrm{Pb}$ concentration up to $400 \mathrm{mg} \mathrm{kg}^{-1}$ increased their root nitrogen contents; as $\mathrm{Pb}$ concentrations further increased to $800 \mathrm{mg} \mathrm{kg}^{-1}$, root nitrogen contents decreased (figure 5). 


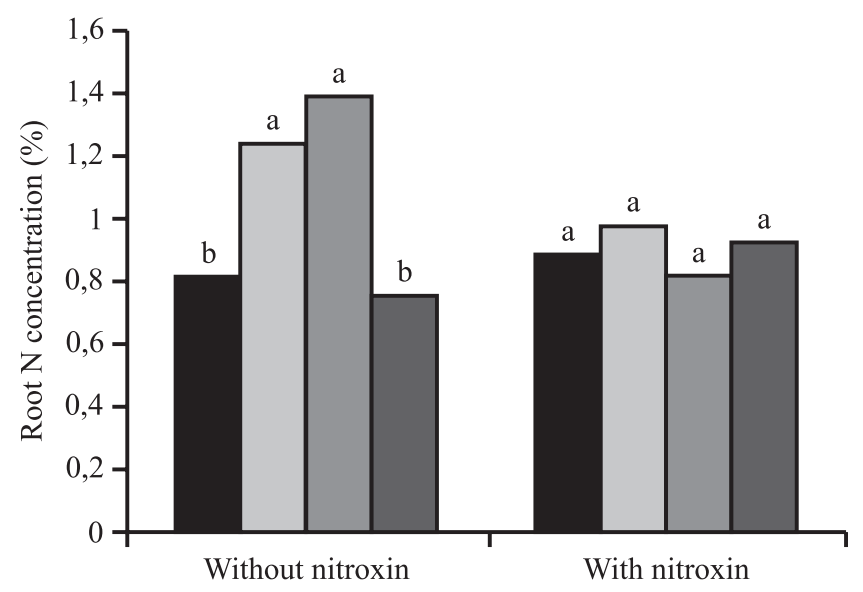

Figure 5. Effects of the interactions between Nitroxin and lead concentrations on root nitrogen concentrations. Columns with the same letter in each group are not significantly different at a $5 \%$ level of probability. $\left(\square=\right.$ Control; $\square=200 \mathrm{mgPb} \mathrm{kg}^{-1}$; $\left.\square=400 \mathrm{mgPb} \mathrm{kg}^{-1} ; \square=800 \mathrm{mgPb} \mathrm{kg}^{-1}\right)$.

\section{Shoot and root phosphorus concentrations}

Phosphorus concentrations in LSCG shoots and roots were significantly affected by Nitroxin and $\mathrm{Pb}$ and their interactions (table 1). Shoot phosphorus concentrations under Nitroxin inoculation conditions decreased with increasing $\mathrm{Pb}$ concentrations (figure 6). In the absence of Nitroxin, soil Pb concentrations up to $200 \mathrm{mg} \mathrm{kg}^{-1}$ increased shoot phosphorus concentrations, while increasing $\mathrm{Pb}$ to $400 \mathrm{mg} \mathrm{kg}^{-1}$ decreased phosphorus concentrations in the shoot; increasing soil $\mathrm{Pb}$ concentrations above $400 \mathrm{mg} \mathrm{kg}^{-1}$ resulted again in increases in shoot phosphorus concentrations (figure 6).

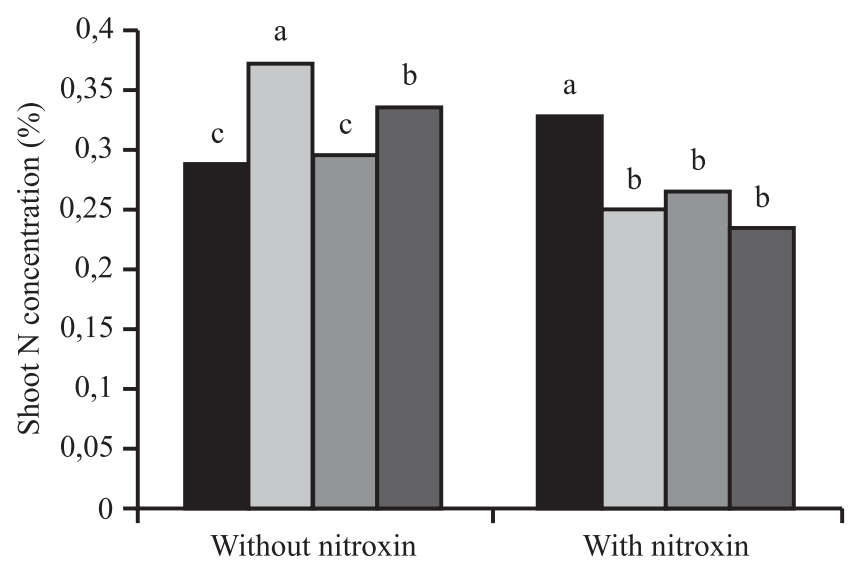

Figure 6. Effects of the interactions between Nitroxin and lead concentrations on shoot phosphorus concentrations. Columns with the same letter in each group are not significantly different at a $5 \%$ level of probability. $\left(\square=\right.$ Control; $\square=200 \mathrm{mgPb} \mathrm{kg}^{-1}$; $\left.\square=400 \mathrm{mgPb} \mathrm{kg}^{-1} ; \square=800 \mathrm{mgPb} \mathrm{kg}^{-1}\right)$.
Under conditions of Nitroxin inoculation, root phosphorus concentrations remained constant with increasing Pb concentrations (figure 7). Without Nitroxin inoculation phosphorus content increase in relation to controls in the range of 200 to $400 \mathrm{mgPb} \mathrm{kg}^{-1}$; but at a concentration of $800 \mathrm{mg} \mathrm{kg}^{-1}$, root phosphorus concentrations decreased.

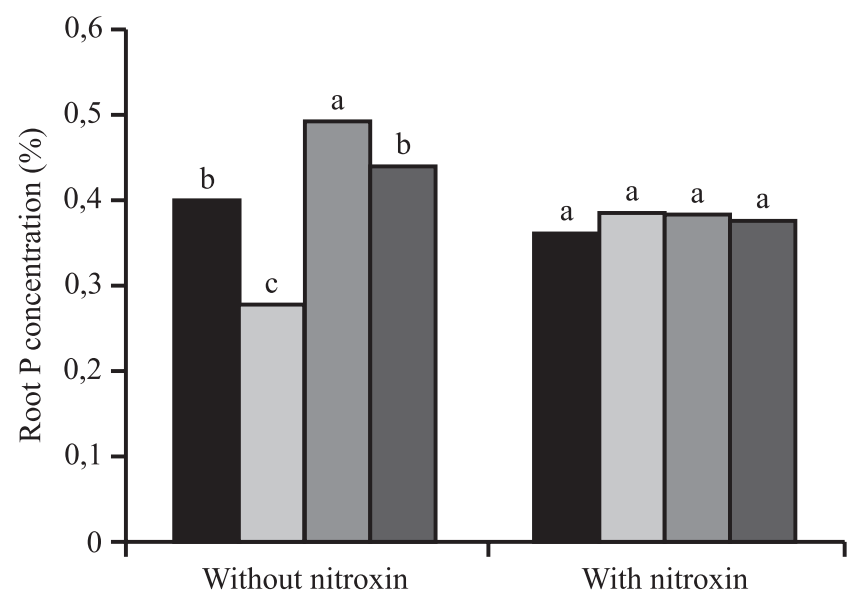

Figure 7. Effects of the interactions between Nitroxin and lead concentrations on root phosphorus concentrations. Columns with the same letter in each group are not significantly different at a $5 \%$ level of probability. ( $=$ Control; $\square=200 \mathrm{mgP} \mathrm{kg} \mathrm{k}^{-1}$; $\left.\square=400 \mathrm{mgPb} \mathrm{kg}^{-1} ; \square=800 \mathrm{mgPb} \mathrm{kg}^{-1}\right)$.

\section{Root and shoot $\mathbf{P b}$ concentrations}

Nitroxin inoculation did not have any significant effect on root and shoot $\mathrm{Pb}$ content, with only soil $\mathrm{Pb}$ levels markedly affecting heavy metal concentrations in plant tissues (table 1), with increasing concentrations of soil $\mathrm{Pb}$ increasing plant tissue $\mathrm{Pb}$ contents. The highest amounts of $\mathrm{Pb}$ were observed in roots and shoots in the $800 \mathrm{mgPb} \mathrm{kg}^{-1}$ dry soil treatments (figure 8). Interactions between Nitroxin and $\mathrm{Pb}$ did not significantly influence the $\mathrm{Pb}$ content of little seed canary grass (table 1 ).

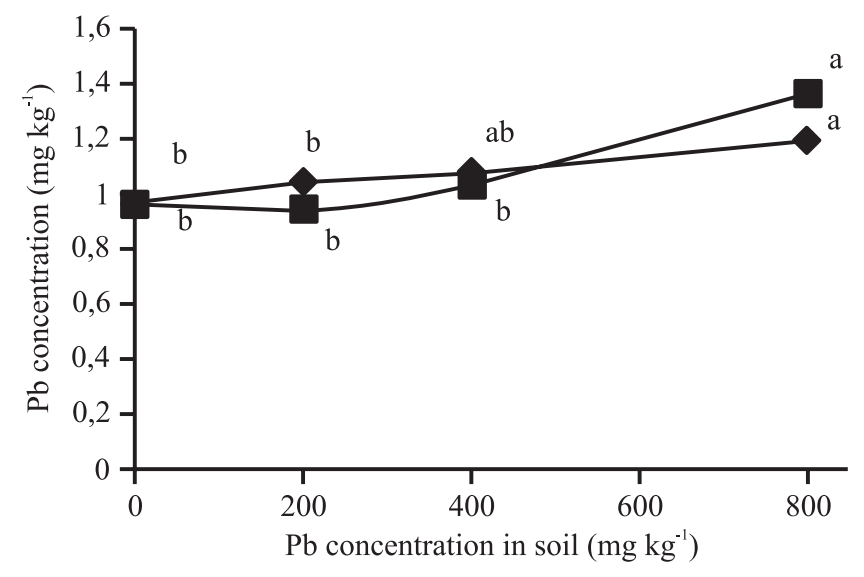




\section{Translocation and bioaccumulation ratios}

The translocation factor of $\mathrm{Pb}$, with or without Nitroxin inoculation, at concentrations of 200 and $400 \mathrm{mgPb} \mathrm{kg}^{-1}$ was $>1$; at concentrations of $800 \mathrm{mgPb} \mathrm{kg}^{-1}$ the $\mathrm{TF}$ was $<1$. The $\mathrm{Pb}$ bioaccumulation factor (BAF), both with and without inoculation of Nitroxin, was $<1$ (table 2).

\section{DISCUSSION}

Lead can inhibit plant growth, and our results indicated that increasing $\mathrm{Pb}$ concentrations caused reductions in leaf, stem, and root dry matter accumulations in little seed canary grass. Diaz-Aguilar et al. (2001), Geebelen et al. (2002), Sinha et al. (2006), and Jayakumar et al. (2007) likewise observed inhibitory effects of $\mathrm{Pb}$

Table 2. Means of the Translocation Factors (TF) and Bioaccumulation Factors (BAF) of Pb in different concentration of that heavy metal, with and without Nitroxin inoculation.

\begin{tabular}{cccccc}
\hline \multirow{2}{*}{$\begin{array}{c}\text { Pb concentrations } \\
\left(\mathrm{mg} \mathrm{kg}^{-1}\right)\end{array}$} & \multicolumn{2}{c}{$\mathrm{TF}$} & & \multicolumn{2}{c}{ BAF } \\
\cline { 2 - 3 } \cline { 5 - 6 } & Without Nitroxin & With Nitroxin & & Without Nitroxin & With Nitroxin \\
\hline 0 & $1.04 \pm 0.18$ & $0.99 \pm 0.01$ & & $0.80 \pm 0.09$ & $0.82 \pm 0.10$ \\
200 & $1.03 \pm 0.23$ & $1.20 \pm 0.10$ & & $0.005 \pm 0.001$ & $0.01 \pm 7.5 \mathrm{e}-05$ \\
400 & $1.06 \pm 0.26$ & $1.03 \pm 0.03$ & & $0.003 \pm 0.001$ & $0.003 \pm 3.75 \mathrm{e}-05$ \\
800 & $0.93 \pm 0.14$ & $0.83 \pm 0.04$ & & $0.002 \pm 6.25 \mathrm{e}-05$ & $0.001 \pm 1.88 \mathrm{e}-05$ \\
\hline
\end{tabular}

* Data are given as means $\pm \mathrm{SD}$ (standard deviation).

on plant growth. Inhibitory effects of $\mathrm{Pb}$ on plants were also reported by Kastori et al. (1998), Tomar et al. (2000), and Munzuroglu \& Geckil (2002). Mukherji \& Maitra (1977) and Carlson et al. (1976) similarly reported inhibitory effects of $\mathrm{Pb}$ on cereal crops and other plants. Lead can directly affect cell elongation by inhibiting cell wall enzymes and plasmalemma ATPase and by dampening electron translocation in photosynthesis and respiration - thus causing reductions in plant growth. Even small amounts of $\mathrm{Pb}\left(1.0 \mathrm{mg} \mathrm{kg}^{-1}\right)$ can decrease mitochondrial respiration (Brekle \& Kahle 1992). Plant biomass reductions due to $\mathrm{Pb}$ exposure are caused by reductions in their photosynthetic and metabolic rates (Sinha et al. 2006).

The inoculation of little seed canary grass with Nitroxin had positive effects on plant growth under $\mathrm{Pb}$ stress, most likely by alleviating $\mathrm{Pb}$ toxicity, and increased shoot yields were observed as compared to treatments without inoculation (Wu et al. 2006). Sharp et al. (2011) reported that plant growth-promoting hormones such as auxin and gibberellin produced by rhizobacteria promoted plants growth under conditions of heavy metal stress. Nitrogen fixing bacteria such as Azotobacter and Azosperillum are responsible for the biological

Figure 8. Effects of soil $\mathrm{Pb}$ concentrations on the $\mathrm{Pb}$ concentrations of roots $(\boldsymbol{\square})$ and shoots $(\boldsymbol{)})$. Points with the same letters on each line are not significantly different at a $5 \%$ level of probability. fixation of $\mathrm{N}_{2}$, which enhances nitrogen availability to plants and increases its concentration in the soil (Glick et al. 1999, Wu et al. 2006, Zhuang et al. 2007). The application of Nitroxin during phytoremediation can therefore be very important due to the important roles of these microorganisms (Burd et al. 2000, Zhuang et al. 2007) in enhancing soil detoxification (Mayak et al. 2004). The plant growth promoting rhizobacteria Kluyvera ascorbata sub165, which was isolated from heavy metal-contaminated soil in Canada, was found to protect canola (Brassica napus L.) against nickel $(\mathrm{Ni})$, lead $(\mathrm{Pb})$, zinc $(\mathrm{Zn})$ and chromium $(\mathrm{Cr})$ toxicity (Burd et al. 1998). Jayakumar et al. (2007) reported that increasing cobalt $(\mathrm{Co})$ concentration from 50 to $250 \mathrm{mg} \mathrm{kg}^{-1}$ decreased the nitrogen content of Raphanus sativa $\mathrm{L}$.

Rother et al. (1983) reported that excess cadmium and $\mathrm{Pb}$ reduced the nitrogen content of Trifolium repens L., while Gomes et al. (1985) demonstrated that heavy metals reduced nitrate uptake by sorghum (Sorghum bicolor (L.) Moench.) roots. In our experiments, reductions in plant root nitrogen contents occurred at the highest concentration of $\mathrm{Pb}$ without Nitroxin inoculation. The constant nitrogen contents of LSCG roots with Nitroxin inoculation could also be due to increased nitrogen translocation. Nitroxin is known to enhance the levels of auxins and gibberellins in plants, and these hormones increase shoot growth and nitrogen translocation to the shoot (Khan 2005). $\mathrm{Wu}$ et al. (2006) noted that rhizobacteria produce a 
variety of growth-promoting hormones (including auxins, gibberellins and B vitamins) that stimulate root exudate production. The enhancement of ammonia concentrations in the rhizosphere by Nitroxin is likewise an important functional factor that can improve plant growth, especially in the presence of root exudates, and would explain why plants inoculated with rhizobacteria have higher nitrogen contents and demonstrate greater growth. These hormones increase nitrogen translocation in plant shoots (Khan 2005).

Our results showed that Nitroxin inoculated plants exposed to high $\mathrm{Pb}$ concentrations had constant amounts of phosphorus in their roots, whereas the same $\mathrm{Pb}$ concentrations reduced the amount of phosphorus in their shoots. There have been reports of adverse effects of $\mathrm{Pb}$ on phosphorus uptake and accumulation in plants. Diaz-Aguilar et al. (2001) and Geebelen et al. (2002), for example, observed that excess $\mathrm{Pb}$ decreased phosphorus concentrations in the shoots and spikes of wheat (Triticum aestivum L.), and a suggested that phosphorus and $\mathrm{Pb}$ formed an insoluble complex. Sinha et al. (2006) reported that $\mathrm{Pb}$ decreased phosphorus concentrations in the shoots and roots of cabbage (Brassica oleracea L.). Ardakani et al. (2009) likewise indicated that $\mathrm{Pb}$ reduced phosphorus accumulation in barley (Hordeum vulgare L.), although Larsson et al. (1998) reported that excess $\mathrm{Pb}$ increased phosphoros concentrations in the roots and shoots of canola.

In our trials, the translocation and bioaccumulation of $\mathrm{Pb}$ in little seed canary grass were not affected by inoculation with Nitroxin. Our review of the literature indicated that there existed a wide range of variations in the Translocation Factor (TF) of $\mathrm{Pb}$. Tang et al. (2009) reported that the TF of Arabis paniculata was $<1$ in the range of $\mathrm{Pb}$ concentration between 9 and 296 $\mu$ mol. Sun et al. $(2008,2009)$ showed that the TF of black nightshade (Solanum nigrum L.) was $>1$, while Rezvani \& Zaefarian (2011) reported that the TF of Aeluropus littoralis changed with differing soil $\mathrm{Pb}$ concentrations.

The observed inefficiency of Nitroxin in enhancing $\mathrm{Pb}$ uptake by little seed canary grass could be due to the inefficient manner in which it increases nitrogen and phosphorus bioavailability, and it may also be inefficient at increasing $\mathrm{Pb}$ solubility and its availability for plants. Huang \& Cunninghan (1996) likewise reported low $\mathrm{Pb}$ solubility as an important inhibitor of $\mathrm{Pb}$ phytoremediation, in agreement with results of Huang et al. (1997). The bioaccumulation of $\mathrm{Pb}$ is dependent on the plant being tested and on soil $\mathrm{Pb}$ concentrations. Rezvani \& Zaefarian (2011) showed that the Pb BAF of
Aeluropus littoralis varied from 0.13 to 1.35 at different soil $\mathrm{Pb}$ concentrations, but the BAF (both with and without Nitroxin inoculation) seen with LSCG was always low. Reductions of the BAF for heavy metals, such as $\mathrm{Zn}$ and $\mathrm{Cd}$ at higher soil metal concentrations, were also reported by Efroymson et al. (2001) and Zhao et al. (2003).

Plants may follow two different strategies of $\mathrm{Pb}$ uptake and translocation. Many plants, such as Thlaspi praecox Wulf., have exclusion strategies that prevent $\mathrm{Pb}$ from entering the plant. These plants can accumulate cadmium $(\mathrm{Cd})$ and zinc $(\mathrm{Zn})$ but exclude $\mathrm{Pb}$ from their tissues (Vogel-Mikus et al. 2005). However, some plants such as Sesbania drummindii (Fabaceae), and some species of Brassicaceae (such as Brassica juncea (L.) Czern.) can accumulate high $\mathrm{Pb}$ concentrations in their roots (Wong et al. 2001).

Our results demonstrated that Nitroxin increased the resistance of little seed canary grass to excess $\mathrm{Pb}$, possibly by the production of antibiotics such as kanamycin, streptomycin, ampicillin, tetracycline, and rifampicin by PGPR (Jiang et al. 2008). Sahi et al. (2002) reported that Sesbania drummondii (Rydb.) Cory could tolerate soil $\mathrm{Pb}$ levels up to $1500 \mathrm{mg} \mathrm{kg}^{-1}$ and could accumulate $40 \mathrm{mgPb} \mathrm{kg}^{-1}$ in its shoots.

Our results also demonstrated that $\mathrm{Pb}$ has a stunting effect on plant growth, with increasing soil $\mathrm{Pb}$ contents causing decreased stem, leaf, and root biomass accumulations. Inoculation with Nitroxin had no marked effect on shoot $\mathrm{Pb}$ concentrations with increasing soil $\mathrm{Pb}$ concentrations. Nitroxin appears to provide protection to little seed canary grass by alleviating $\mathrm{Pb}$ toxicity and reducing the concentrations of this heavy metal in the plant by stimulating phytohormone production. Nitroxin influenced root $\mathrm{Pb}$ uptake, and its $\mathrm{Pb}$ translocation and bioaccumulation factors indicated that LSCG accumulated $\mathrm{Pb}$ in its roots but inhibited $\mathrm{Pb}$ translocation into the shoot. We therefore conclude that little seed canary grass is a $\mathrm{Pb}$ excluding plant.

\section{REFERENCES}

Andrade G, Mihara KL, Linderman RG, Bethlenfalvay GJ. 1997. Bacteriafrom therhizosphereand hyphorhizosphere soils of different arbuscular mycorrhizal fungi. Plant Soil 192:71-79.

Ardakani MR, Teimuri S, Rezvani M, Fathollahi H, Khorasani A, Rejali F, Raza A, Zafarian F. 2009. Evaluation of mychorrhizae symbiosis efficiency with barley (Hordeum vulgare L.) through ${ }^{32} \mathrm{P}$ uptake under soils contaminated with heavy metals. International Journal of Botany 5:236-243. 
Breckle SW, Kahle H. 1992. Effects of toxic heavy metals $(\mathrm{Cd}, \mathrm{Pb})$ on growth and mineral nutrition of Fagus sylvatica. Vegetadology 101:43-53.

Burd GI, Dixon DG, Glick BR. 1998. A plant growth promoting bacterium that decreases nickel toxicity in seedlings. Applied and Environmental Microbiology 64:3663-3668.

Burd GI, Dixon DG, Glick RR. 2000. Plant growth promoting bacteria that decrease heavy metal toxicity in plants. Canadian Journal of Microbiology 46:237-245.

Carlson RW, Bazzaz FA, Stukel JJ, Wedding, JB. 1976. Physiological effects, wind re-entrainment and rain wash of lead aerosol particulates deposited on plant leaves. Environmental Science and Technology 10: 1139-1142.

Cluis C. 2004. Junk-greedy greens: phytoremediation as a new option for soil decontamination. BioTeach Journal 2:60-67.

Diaz-Aguilar I, Larque-Saavedra MV, Alcantar-Gonzalez G, Carrillo-Gonzalez R, Vazquez-Alarcon A. 2001. Alteration of some physiological processes in wheat by lead additions. Revista International de Contamination Ambiental 17:79-90.

Efroymson RA, Sample BE, Suter GW. 2001. Uptake of inorganic chemicals from soil by plant leaves: regressions of field data. Environmental Toxicology and Chemistry 20:2561-2571.

Frankenberger WT, Tabatbai MA, Adriano DC, Dopner HE. 1996. Bromine, chlorine, and fluorine. In Method of soil analysis, Chemical methods (JM Bartels, JM Bigham, eds.). Soil Science Society of America Book Series, Madison, part 3, p.833-868.

Fayiga AQ, Ma LQ. 2006. Using phosphate rock to immobilize metals in soils and increase arsenic uptake in Pteris vittata. Science of the Total Environment 359:17-25.

Gadd GM. 2001. Metal transformations. In Fungi in remediation (GM Gadd, ed.). Cambridge University Press, Cambridge, p.250-382.

Geebelen W, Vangronsveld J, Adriano DC, Poucke LCV, Clijsters H. 2002. Effect of Pb-EDTA and EDTA in oxidative stress reactions and mineral uptake in Phaseolus vulgaris. Physiologia Plantarum 115: 377-384.

Glick BR, Patten CL, Holguin G, Penrose DM. 1999. Biochemical and genetic mechanisms used by plant growth-promoting bacteria. Imperial College Press, London.

Gomes MMS, Cambrai J, Santsnna R. 1985. Aluminum effects on uptake and translocation in sorghum (Sorghum bicolor (L.). Moench.). Journal of Plant Nutrition 8: 457-465.

Henry JR. 2000. An overview of the phytoremediation of lead and mercury. National Network of Environmental Management Studies (NNEMS). Environmental Protection Agency, Washington, DC, p.1-31.
Huang JWS, Cunningham D. 1996. Lead phytoextraction: species variation in lead uptake and translocation. New Phytologist 134:75-84.

Huang J, Chen J, Berti W, Cunningham S. 1997. Phytoremediation of lead-contaminated soils: role of synthetic chelates in lead phytoextraction. Environmental Science \& Technology 31:800-805.

Jayakumar K, Jaleel CA, Vijayarengan P. 2007. Changes in growth, biochemical constituents, and antioxidant potentials in radish (Raphanus sativus $\mathrm{L}$.) under cobalt stress. Turkish Journal of Biology 31:127-136.

Jiang C, Sheng X, Qian M, Wang Q. 2008. Isolation and characterization of a heavy metal-resistant Burkholderia sp. from heavy metal-contaminated paddy field soil and its potential in promoting plant growth and heavy metal accumulation in metal-polluted soil. Chemosphere 72:157-164.

Kastori R, Plesnicar M, Sakac Z, Pankovic D, ArsenijevicMaksimovic I. 1998. Effect of lead excess on sunflower growth and photosynthesis. Journal of Plant Nutrition 21:75-85.

Khan AG. 2006. Mycorrhizoremediation: an enhanced form of phytoremediation. Journal of Zhejiang University (Science B) 7:503-514.

Khan AG. 2005. Role of soil microbes in the rhizospheres of plants growing on trace metal contaminated soils in phytoremediation. Journal of Trace Elements in Medicine and Biology 18:355-364.

Larsson H, Bornman JF, Asp H. 1998. Influence of UV-B radiation and $\mathrm{Cd}$ on chlorophyll fluorescence, growth and nutrient content in Brassica napus. Journal of Experimental Botany 323:1031-1039.

Ma LQ, Komar KM, Tu C, Zhang W, Cai Y, Kenelly ED. 2001. A fern that hyper accumulates arsenic. Nature 409:579-582.

Mayak S, Tirosh S, Glick BR. 2004. Plant growth promoting bacteria that confer resistance to water stress in tomatoes and peppers. Plant Science 166:525-530.

Mukherji S, Maitra P. 1977. Growth and metabolism of germinating rice (Oryza sative L.) seeds as influenced by toxic concentrations of lead. Zeitschrift für Pflanzenphysiologie 81:26-33.

Munzuroglu O, Geckil H. 2002. Effects of metals on seed germination, root elongation and coleoptile and hypocotyl growth in Triticum aestivum and Cucumis sativus. Archives of Environmental Contamination and Toxicology 23:203-213.

Page AL, Miller RH, Keeney DR. 1982. Method of soil analysis: chemical and microbiological properties, part 2, 2nd ed., American Society of Agronomy, Soil Science Society of America, Madison.

Rother JA, Millbank JW, Thronton I. 1983. Nitrogen fixation by white clover (Trifolium repens) in grassland on soils contaminated with $\mathrm{Cd}, \mathrm{Pb}$ and $\mathrm{Zn}$. Journal of Soil Science 34:127-136. 
Rezvani M, Zaefarian F. 2011. Bioaccumulation and translocation factors of cadmium and lead in Aeluropus littoralis. Australian Journal of Agricultural Engineering 2:114-119.

Sahi SV, Bryant NL, Sharma NC, Singh SR. 2002. Characterization of a lead hyperaccumulators, Sesbania drummondii. Environmental Science \& Technology 36:4676-4680.

Salt DE, Smith RD, Raskin I. 1998. Phytoremediation. Annual Review of Plant Physiolgy and Plant Molecular Biology 49:643-68.

Sinha P, Dube BK, Sriastava P, Chatterjee C. 2006. Alteration in uptake and translocation of essential nutrients in cabbage by excess lead. Chemosphere 65:651-656.

Sharp RG, Chen L, Davies WJ. 2011. Inoculation of growing media with the rhizobacterium Variovorax paradoxus 5C-2 reduces unwanted stress responses in hardy ornamental species. Scientia Horticulturae 129: 804-811.

Sun TH, Li PJ, Zhou QX. 2005. The mechanism of soil pollution and remediation technology. Science Press, Beijing, China.

Sun YB, Zhou QX, Diao CY. 2008. Effects of cadmium and arsenic on growth and metal accumulation of $\mathrm{Cd}-$ hyperaccumulator Solanum nigrum L. Bioresource Technology 99:1103-1110.

Sun YB, Zhou QX, Wang L, Liu W. 2009. Cadmium tolerance and accumulation characteristics of Bidens pilosa L. as a potential Cd-hyperaccumulator. Journal of Hazardous Material 161:808-814.

Sun YP, Unestam T, Lucase SD, Johanson KJ, Kenne L, Finlay R. 1999. Exudation-reabsorption in a mycorrhizal fungus, the dynamic interface for interaction with soil and soil micro-organisms. Mycorrhiza 9: 137-144.

Suresh B, Ravishankar GA. 2004. Phytoremediation: a novel and promising approach for environmental clean-up. Critical Reviews in Biotechnology 24:97-124.
Tang YT, Rong-Liang Qiu RL, Zenga JW, Ying RR, Yu FM, Zhou XY. 2009. Lead, zinc, cadmium hyperaccumulation and growth stimulation in Arabis paniculata Franch. Environmental and Experimental Botany 66:126-134.

Tintinelli JE, Krome RL, Ruiz E. 1992. Emergency medicine, 3rd ed. McGraw Hill, New York.

Tomar M, Kaur I, Neelu A, Bhatnagar K. 2000. Effect of enhanced lead in soil on growth and development of Vigna radiate (Linn.) Wilczek. Indian Journal of Plant Physiology 5:13-18.

Van der Lelie D, Schwitzguebel JP, Glass DJ, Vangronsveld J, Baker A. 2001. Assessing phytoremediation's progress in the United States and Europe. Environmental Science \& Technology 35:446-452.

Vogel-Mikus K, Drobne D, Regvar M. 2005. Zn, Cd and Pb accumulation and arbuscular mycorrhizal colonisation of pennycress Thlaspi praecox Wulf. (Brassicaceae) from the vicinity of a lead mine and smelter in Slovenia. Environmental Pollution 133:233-242.

Wong JW, Lai CKM, Su DS, Fang M. 2001. Availability of heavy metals for Brassica chinensis grown in an acidic loamy soil amended with a domestic and an industrial sewage sludge. Water, Air and Soil Pollution 128:339353.

Wu SC, Cheung KC, Luo YM, Wong MH. 2006. Effects of inoculation of plant growth-promoting rhizobacteria on metal uptake by Brassica juncea. Environmental Pollution140:124-135.

Zhang WH, Cai Y, Tu C, Ma QL. 2002. Arsenic speciation and distribution in an arsenic hyperaccumulating plant. Science of the Total Environment 300:167-177.

Zhao FJ, Lombi E, Mc Grath SP. 2003. Assessing the potential for zinc and cadmium phytoremediation with the hyperaccumulator Thlaspi caerulescens. Plant Soil 249:37-43.

Zhuang X, Chen J, Shim H, Bai Z. 2007. New advances in plant growth-promoting rhizobacteria for bioremediation. Environment International 33:406-413. 